\title{
ANALISIS KELAYAKAN TARIF AIR BERDASARKAN PERATURAN MENTERI DALAM NEGERI NOMER 23 TAHUN 2006 DATA TAHUN 2009 S.D 2012 STUDY KASUS DI PDAM TIRTA DHARMA KABUPATEN SLEMAN
}

\author{
Isna Putri Indayani* \\ Sunarto \\ Program Studi Akuntansi, Fakultas Ekonomi \\ Universitas Sarjanawiyata Tamansiswa Yogyakarta \\ *Email : isna_indayany@yahoo.com
}

\begin{abstract}
Sleman is Badan Usaha Milik Daerah engaged in water services. Apart from being required to be able to meet the water needs of the customer, PDAM Sleman should be wise in determining water rates are economically viable in order to cover expenses incurred to earn the income. Therefore, analysis of water rates is needed to support revenue growth and taps in accordance with Peraturan Menteri Dalam Negeri Nomor 23 Tahun 2006 article 5 paragraf lof the PDAM revenues must meet cost recovery principle (full cost recovery).

In examining the water use rate formula of Peraturan Menteri Dalam Negeri Nomor 23 Tahun 2006 and the data used is the financial statement data PDAM Sleman 2009 till 2012. The calculations show the basic water rates, low rates, and the rates prevailing on the taps full Sleman not meet the principle of full cost recovery

From the results of the study also note that the rate of water from PDAM Sleman 2009 data up to 2012 have not been economically viable because they can not cover the entire cost of business or do not meet the principle of full cost recovery.
\end{abstract}

\section{Keyword: full cost recovery, cost of business, price of water}

\section{PENDAHULUAN}

Air merupakan kebutuhan dasar yang sangat penting bagi manusia dan makhluk hidup lainnya. Hampir seluruh kegiatan yang dilakukan manusia membutuhkan air, mulai dari membersihkan diri, membersihkan ruangan tempat tinggal, menyiapkan makanan dan minuman sampai dengan aktivitas-aktivitas lainnya.. Maryono (2006) mengatakan bahwa ketersediaan air bersih merupakan hak bagi setiap warga masyarakat sehingga pemerintah memiliki kewajiban untuk menyediakannya. Hal itu juga dikuatkan dalam bunyi Undang-Undang Dasar 45 pasal 33 ayat 3 bumi, air, dan kekayaan alam yang terkandung didalamnya dikuasai oleh Negara dan dipergunakan untuk sebesar-besarnya kemakmuran rakyat. Isi ayat pasal tersebut bermakna bahwa segala sesuatu mengenai sumber daya alam termasuk di dalamnya air beserta kekayaan alam lainnya milik Negara Kesatuan Republik Indonesia (NKRI), dan pemerintah dengan segenap lembaga pengelolanya dipergunakan untuk memakmurkan dan mensejahterakan rakyat Indonesia seluruhnya. Demi mendukung kinerja pemerintah tersebut, dibentuk lembagalembaga yang dikelola untuk mengurus dan mengelola elemen-elemen alam milik bumi Indonesia antara lain PDAM yang ditunjuk pemerintah untuk mengelola air bersih masyarakat.

Berdasarkan Undang-undang Nomor 5 tahun 1962 pasal 5 ayat 1 menyebutkan bahwa Perusahaan Daerah adalah kesatuan produksi yang bersifat memberi jasa, menyelenggarakan kemanfaatan umum dan memupuk pendapatan. Dalam hal ini, Sumarno (2005) mengatakan Perusahaan 
Daerah Air Minum (PDAM) yang merupakan salah satu perusahaan daerah, selain melakukan aktivitas sosial juga memiliki fungsi membangun, memelihara, dan menjalankan operasi sarana penyediaan air minum, mengajar, menyempurnakan dan mengawasi pemakaian air secara merata dan efisien, menyelenggarakan pengaturan untuk mencegah adanya pengambilan air secara tidak legal, menyelenggarakan pelayanan air minum kepada masyarakat secara tertib dan teratur.

Selain bertugas untuk mengelola air bersih, PDAM juga berkewajiban untuk menjamin kualitas air bersih untuk masyarakat. Berdasarkan Peraturan Menteri Kesehatan Republik Indonesia Nomor 492/Menkes/Per/IV/2010 tentang Persyaratan Kualitas Air Minum pasal 2 menyebutkan setiap penyelenggara air minum wajib menjamin air minum yang diproduksinya aman bagi kesehatan. Pengadaan air dijelaskan pada pasal 1 adalah badan usaha milik negara/badan usaha milik daerah, koperasi, badan usaha swasta, usaha perorangan, kelompok masyarakat dan/ atau individual yang melakukan penyelenggaraan penyedia air minum.

Berdasarkan hal tersebut untuk dapat memberikan pelayanan secara maksimal dalam menentukan tarif atau tarif jual air, PDAM mengacu pada Peraturan Menteri dalam Negeri Nomor 23 Tahun 2006 pasal 5 ayat 2 yang menyebutkan pemulihan biaya penuh (full cost recovery) dicapai dari hasil perhitungan tarif rata-rata minimal sama dengan biaya dasar. Dampak tarif yang tidak full cost recovery bagi PDAM adalah kesulitan dalam mengalokasikan investasi pengembangan pelayanan, serta biaya pemeliharaan dan kualitas pelayanan cenderung menurun. Atas dasar itulah diperlukan penetapkan tarif air bersih secara full cost recovery sehingga pihak penyedia air dapat menilai alternatif tarif air bersih yang paling optimal untuk PDAM dan masyarakat.

Berdasarkan informasi diatas penulis tertarik untuk mengambil penelitian Analisis Kelayakan Tarif Air Berdasarkan Peraturan
Menteri Dalam Negeri Nomor 23 Tahun 2006 Data Tahun 2009 s.d 2012, kasus penelitian di daerah kabupaten Sleman maka studi kasus di PDAM Tirta Dharma Kabupaten Sleman.

\section{LANDASAN TEORI}

\section{Pengertian Air Minum}

Air minum mempunyai beberapa pengertian. diantaranya sebagai berikut:

a. Menurut Rudi Gunawan

"Air minum adalah air untuk kebutuhan hidup rumah tangga, yang mencakup air untuk minum dan masak, air mandi, air cuci dan untuk pembersihan rumah (Sumber)

b. Menurut Sarwoko Mangkoedihardjo dan Ganjar Samudro

"Air minum adalah cairan $\mathrm{H}_{2} \mathrm{O}$ berkandungan zat-zat fisik kimia yang menyehatkan kehidupan

c. Menurut Hamidah Harahap

Air yang kualitasnya memenuhi syarat kesehatan dan dapat langsung diminum"

d. Menurut Peraturan Menteri Kesehatan Republik Indonesia Nomor 493/Menkes/Per/IV/2010

"Air minum adalah air yang melalui proses pengolahan atau tanpa proses pengolahan yang memenuhi syarat kesehatan dan dapat langsung diminum

e. Menurut Peraturan Pemerintah Nomor 16 Tahun 2005

"Air minum rumah tangga yang melalui proses pengolahan atau tanpa proses pengolahan yang memenuhi syarat kesehatan dan dapat langsung dapat diminum

f. Menurut Peraturan Bupati Sleman Nomor 28 Tahun 2012

"Air bersih yang digunakan untuk keperluan sehari-hari yang kualitasnya memenuhi syarat kesehatan dan dapat diminum apabila sudah masak

Dengan demikian air minum itu sendiri adalah air bersih yang langsung dapat diminum apabila sudah masak dan tidak membahayakan kesehatan. 
Air minum yang baik adalah air minum yang tidak menganggu kesehatan manusia. Adapun air minum yang baik harus memenuhi syarat-syarat fisik, kimia dan bakteriologis yang ditentukan oleh Dinas Kesehatan Negara. Syarat-syarat air minum menurut Gunawan (2009) ialah:
a. Harus jernih, bersih dan tidak berwarna.
b. Tidak berbau dan tidak mempunyai rasa apapun.

c. Suhu air yang disukai yang segar, sehingga dapat menghilangkan haus, tidak perlu terlalu dingin teapi mendekati suhu udara segar yang berkisar antara 20-26 C.

d. Asam Karbon $\left(\mathrm{CO}_{2}\right)$ tidak boleh ada dalam air minum, karena sifatnya agresif merusak pipa logam.

e. Asam Nitrit $\left(\mathrm{NO}_{2}\right)$ dan Amoniak $\left(\mathrm{NH}_{4}\right)$ tidak boleh ada, karena zat-zat ini menunjukkan adanya pengotoran (kontaminasi) bahan organik.

f. Timah $(\mathrm{Pb})$ tidak boleh ada, karena beracun, sebab itu pipa dari timah dilarang digunakan.

g. Kadar besi (Fe) kurang dari 0,2 mg per liter air. Bila kadarnya besar akan memberi rasa kurang enak pada air minum dan dapat merusak warna baju jika air digunakan untuk mencuci.

h. Kadar seng ( $\mathrm{Zn})$ kurang dari $5 \mathrm{mg}$ per liter air.

i. $\quad$ Kadar tembaga $(\mathrm{Cu})$ kurang dari $1 \mathrm{mg}$ per liter air.

j. Kadar garam kalsium (Ca) atau magnesium (Mg) antara 50-100 mg per liter air. Kandungan garam yang lebih banyak menyebabkan air menjadi keras sifatnya dan menimbulkan kerak dalam ketel air minum.

k. Air minum harus mengandung iodium untuk mencegah penyakit strauma (gondok).

1. Air minum juga harus mengandung cukup fluorin (F). Kekurangan fluorin akan menyebabkan gigi mudah rusak/berlubang (caries dentis).

m. Kuman yang terdapat dalam $1 \mathrm{cc}$ air minum harus kurang dari 100 kuman. n. Bakteri coli tidak boleh ada dalam 100 cc air minum, karena bakteri coli dapat dipakai sebagai petunjuk untuk mngetahui apakah air sudah tercemar oleh tinja kotoran (faeses), karna bakteri coli adalah penyebab penyakit perut.

o. Bakteri-bakteri patogen, penyebab pnyakit kolera, tifus, disentri, dan gastroenteritis tidak boleh ada dalam air minum.

\section{Pajak Air Tanah}

Pajak daerah sendiri terdapat beberapa definisi yaitu:

1. Menurut Husain Umar

"Pajak Daerah adalah adalah pajak yang dipungut oleh pemerintah daerah dan digunakan untuk membiayai rumah tangga daerah"

2. Menurut Sugianto

"Pajak Daerah adalah adalah pajak yang dipungut oleh pemerintah daerah yang dalam pelaksanaanya sehari-hari dilakukan oleh Dinas Pendapatan Daerah"

3. Menurut Irwansyah Lubis dan

Rayendra L. Toruan

"Pajak Daerah adalah kontribusi wajib kepada daerah yang terutang oleh orang pribadi atau badan yang bersifat memaksa berdasarkan Undang-

4. Berdasarkan Undang-Undang No. 28 Tahun 2009 tentang Pajak Daerah dan Retribusi Daerah pasal 1 ayat 10 pajak daerah adalah kontribusi wajib kepada Daerah yang terutang oleh orang pribadi atau badan yang bersifat memaksa berdasarkan Undang-Undang, dengan tidak mendapatkan imbalan secara langsung dan digunakan untuk Daerah bagi sebesar-besarnya kemakmuran rakyat

Sehingga dapat disimpulkan pajak daerah adalah pajak yang dipungut oleh 
pemerintah daerah kepada wajib pajak yang bersifat memaksa berdasarkan undangundang dan digunakan untuk kemakmuran masyarakat.

Salah satu pajak daerah adalah pajak air tanah, berdasarkan Peraturan Daerah Kabupaten Sleman Nomor 13 Tahun 2010 pasal 1 disebutkan pajak air tanah adalah pajak atas pengambilan dan atau pemanfaatan air tanah. Pengambilan dan pemanfaatan air tanah dalam pasal 1 mempunyai pengertian bahwa setiap kegiatan pengambilan dan pemanfaatan air tanah yang dilakukan dengan cara penggalian, pengeboran, penurapan, atau cara lain untuk dimanfaatkan airnya untuk tujuan lain. Namun terdapat pula objek yang dikecualikan dari objek pajak yaitu:

a. Keperluan dasar rumah tangga

b. Pengairan pertanian dan perikanan

c. Peribadatan

d. Kegiatan Sosial

Pajak yang terutang dipungut di wilayah daerah tempat air diambil dan besaran pokok pajak yang terhutang dihitung dengan cara mengalikan tarif pajak yang ditetapkan yaitu sebesar $20 \%$ dengan nilai perolehan air tanah. Nilai perolehan air tanah didapat dari penghitungan volume air yang diambil dikalikan Tarif Dasar Air (HDA).

\section{Jaminan dan Subsidi Bunga oleh Pemerintah}

Air minum merupakan salah satu kebutuhan dasar penduduk yang perlu diupayakan agar senantiasa tersedia dalam jumlah yang cukup merata dan mutu yang baik. Dalam rangka percepatan penyediaan air minum bagi penduduk dan untuk mencapai millenium development goals, perlu diberikan akses pembiayaan bagi PDAM untuk memperoleh kredit investasi dari perbangkan nasional. Untuk mendorong perbangkan nasional memberikan kredit investasi kepada PDAM, dipandang perlu memberikan jaminan dan subsidi bunga oleh pemerintah pusat atas kewajiban pembayaran kredit investasi PDAM kepada bank. Atas dasar itulah dasar ditetapkannya Peraturan Presiden tentang Pemberian Jaminan dan
Subsidi Bunga oleh Pemerintah Pusat dalam rangka Percepatan Penyediaan Air Minum.

Ketentuan dan besaran pinjaman untuk PDAM yaitu $70 \%$ merupakan jaminan dari pemerintah pusat sedangkan sisanya sebesar $30 \%$ menjadi resiko bank yang memberikan kredit investasi. Dalam pasal 3 dijelaskan bahwa :

a. Dalam hal PDAM gagal bayar atas sebagian atau seluruh kewajiban yang telah jatuh tempo sesuai dengan perjanjian pinjaman. Pemerintah Pusat menanggung sebesar 70\% (Tujuh Puluh Persen) dan bank menanggung 30\% (Tiga Puluh Persen) dari jumlah gagal bayar.

b. Berdasarkan realisasi pembayaran jaminan Pemerintah Pusat, dilakukan pembagian pembebanan masingmasing Pemerintah Pusat menanggung sebesar 40\% (empat puluh persen) dan Pemerintah Daerah menanggung sebesar 30\% (Tiga Puluh Persen) dihitung dari seluruh kewajiban PDAM yang gagal bayar.

c. Pelaksanaan pembayaran jaminan Pemerintah Pusat sebesar 40\% (Empat Puluh Persen) selanjutnya diperhitungkan sebagai pinjaman dari Pemerintah Pusat kepada PDAM dengan persyaratan pinjaman yang diatur dalam perjanjian pinjaman antara Pemerintah Pusat dan PDAM.

d. Pemerintah Daerah menetapkan status dana yang dibayarkan sebesar 30\% (Tiga Puluh Persen) sebagai penyertaan modal Pemerintah Daerah, atau hibah Pemerintah Daerah kepada PDAM.

Untuk mendapatkan jaminan dari Pemerintah Pusat, disebutkan dalam pasal 5 PDAM harus memenuhi persyaratan sebagai berikut:

a. Setiap pemberian jaminana Pemerintah Pusat didahului dengan perjanjian induk (umbrlla agrement) antara Pemerintah Pusat c.q Menteri Keuangan, Pemerintah Daerah, dan PDAM. Kurang lebih memuat ketentuan-ketentuan sebagai berikut: 
1) Pemerintah Pusat melaksanakan pembayaran sebesar $70 \%$ (tujuh puluh persen) dari seluruh kewajiban pembayaran kembali kredit investasi PDAM yang gagal bayar.

2) Setiap pelaksanaan pembayaran jaminan Pemerintah Pusat sebesat $40 \%$ (empat puluh persen) menjadi pinjaman PDAM kepada Pemerintah Pusat.

3) Pernyataan

Gubernur/Walikota/Bupati

mengenai kesediaan untuk menanggung beban sebesar $30 \%$ (tiga puluh persen) dari APBD, dan/atau mengkonversi beban sebesar 30\% (tiga puluh persen) menjadi utang Pemerintah Daerah kepada Pemerintah Pusat.

4) Pernyataan

Gubernur/Walikota/Bupati mengenai kesediaan dilakukan pemotongan Dana Alokasi Umum dan/atau Dana Bagi Hasil apabila Pemerintah Daerah tidak melakukan pembayaran pinjaman sebagai konversi dari pembagian pembebanan.

b. Pernyataan kesediaan Gubernur/Walikota/Bupati dan wajib mendapatkan persetujuan dari Dewan Perwakilan Rakyat Daerah. Hal itu dilakukan sebelum penandatanganan perjanjian induk (umbrella agreement)

Dalam memperoleh jaminan Pemerintah Pusat, hanya PDAM yang memenuhi ketentuan sebagai berikut:

a. Untuk PDAM yang tidak mempunyai tunggakan kepada Pemerintah Pusat, wajib memenuhi persyaratan sebagai berikut:

1) Hasil audit kinerja oleh Badan Pengawasan Keuangan dan Pembangunan yang menunjukkan kinerja sehat
2) PDAM telah melakukan penetapan tarif rata-rata yang lebih besar dari seluruh biaya rata-rata per unit (full cost recovery) selama masa penjaminan.

b. Untuk PDAM yang mempunyai tunggakan kepada Pemerintah Pusat, diwajibkan telah memenuhi persyaratan program restrukturasi dan mendapat persyaratan program restrukturisasi dan mendapat persetujuan Menteri Keuangan.

Dalam pemberian subsidi bunga, tingkat bunga kredit investasi yang disalurkan bank kepada PDAM, ditetapkan sebesar BI rate ditambah paling tinggi 5\% (lima persen) dengan ketentuan:

a. Tingkat bunga sebesar BI rate ditanggung PDAM

b. Selisih bunga di atas BI rate paling tinggi sebesar 5\% (lima persen) menjadi subsidi yang ditanggung pemerintah pusat.

Agar program pemberian jaminan dan subsidi bunga berjalan dengan baik, maka berdasarkan pasal 16 dibutuhkan pemantauan, evaluasi dan pengawasan sebagai berikut:

a. Pemantauan, evaluasi dan pengawasan atas pemberian jaminan dan subsidi bunga kepada PDAM dalam rangka percepatan penyediaan air minum dilakukan oleh Tim Koordinasi yang dibentuk oleh menteri Koordinasi Bidang Perekonomian.

b. Tim Koordinasi terdiri dari Menteri Koordinator Bidang Perekonomian, Menteri Keuangan, Menteri Pekerjaan Umum, Menteri Dalam Negeri, Menteri Negara Perencanaan Pembangunan Nasional/Kepala Badan Perencanaan Pembangunan nasional, dan Kepala Badan Pengawasan Keuangan dan Pembangunan.

c. Tim Koordinasi mempunyai tugas sebagai berikut: 
1) Melaksanakan sosialisasi pelaksanaan penjaminan dan subsidi bunga dalam rangka perepatan penyediaan air minum.

2) Melaksanakan koordinasi dengan instansi terkait dalam rangka pemantauan, evaluasi, dan pengawasan atas pelaksanaan penjaminan dan subsidi bunga dalam rangka percepatan penyediaan air minum.

3) Melaksanakan pemantauan, evaluasi dan pengawasan atas pelaksanaan penjaminan dan subsidi bunga dalam rangka percepatan penyediaan air minum.

d. Dalam melaksanakan tugasnya, Tim Koordinasi dapat meminta bantuan Kantor Akuntan Publik, atau Badan Pengawasan Keuangan dan Pembangunan untuk melakukan audit keuangan atas pekerjaan yang dibiayai dengan kredit investasi.

e. Ketentuan lebih lanjut mengenai susunan organisasi, dan tata kerja Tim Koordinasi ditetapkan dengan Peraturan Menteri Koordinasi

Bidang

Perekonomian.

\section{Tarif Air Minum}

Tarif air sendiri berdasarkan Peraturan Menteri Dalam Negeri Nomor 23 Tahun 2006 adalah kebijakan tarif jual air minum dalam satuan $\left(\mathrm{m}^{3}\right)$ atau satuan volume lainnya sesuai kebijakan yang ditentukan Kepala Daerah dan PDAM yang bersangkutan. Dalam peraturan tersebut juga disebutkan bahwa tarif air terdiri dari 3 kelompok yaitu:

a. Tarif Rendah yaitu tarif bersubsidi yang nilainya lebih rendah dibanding biaya dasar.

b. Tarif Dasar yaitu tarif yang nilainya sama atau ekuivalen dengan biaya dasar.

c. Tarif Penuh yaitu tarif yang nilainya lebih tinggi dibanding biaya dasar karena mengandung tingkat kuntungan dan kontra subsidi silang.

d. Tarif Kesepakatan yaitu nilainya berdasarkan kesepakatan antara PDAM dengan pelanggan.

Tarif diatas dibedakan berdasarkan 4 kelompok pelanggan yaitu:

a. Kelompok I adalah pelanggan yang membayar tarif rendah untuk memenuhi standar kebutuhan pokok air minum.

b. Kelompok II adalah pelanggan yang membayar tarif dasar untuk memenuhi standar kebutuhan pokok air minum.

c. Kelompok III adalah pelanggan yang membayar tarif penuh untuk memenuhi standar kebutuhan pokok air minum.

d. Kelompok Khusus adalah pelanggan yang membayar tarif air minum berdasarkan kesepakatan.

Berdasarkan Peraturan Bupati Sleman Nomor 28 Tahun 2012, empat kelompok diatas diklasifikasikan sebagai berikut:

\section{Tabel 1}

\section{Tabel Klasifikasi Kelompok Pelanggan}

\begin{tabular}{lll}
\hline No & Kelompok & Klasifikasi \\
\hline & Kelompok & \\
1 & I & Sosial Umum \\
& & Sosial Khusus \\
\hline \multirow{3}{*}{2} & Kelompok & Rumah Tangga \\
& II & A1 \\
& & Rumah Tangga \\
& & A2 \\
& & Rumah Tangga \\
& & B \\
& & Instansi \\
& & Pemerintah \\
& & Tinggi \\
\hline \multirow{3}{*}{3} & Kelompok & \\
& III & Niaga Kecil \\
& & Industri Kecil \\
\hline \multirow{3}{*}{4} & Kelompok & \\
& IV & Niaga Besar \\
& & Industri Besar \\
& & Bandar Udara \\
\hline
\end{tabular}

Tujuan pembagian kelompok pelanggan adalah untuk menciptakan tarif 
yang adil dan terjangkau sesuai dengan kemampuan pelanggan menurut tingkat pemakainnya, untuk memungkinkan terciptanya subsidi silang, dan untuk kepentingan kesinambungan pelayanan PDAM. Dengan adanya pengelompokan pelanggan tersebut, dapat ditetapkan kelompok pelanggan yakni:
a. Layak mendapat subsidi
b. Tidak mendapat subsidi
c. Memberi subsidi dengan tarif yang mengandung tingkat keuntungan

Dengan demikian, pengelompokan pelanggan tersebut pada hakekatnya merupakan strategi penetapan tarif air minum guna mewujudkan misi PDAM yaitu sebagai Badan Usaha Milik Daerah yang mampu menghasilkan keuntungan untuk mempertahankan dan meningkatkan pelayanan umum, dikelola dengan prinsip tata kelola perusahaan yang baik, dengan tetap memperhatikan fungsi sosial bagi pemenuhan kebutuhan dasar masyaakat.

Jenis-jenis pelanggan yang dilayani oleh PDAM sangat bervariasi. Tidak seluruh jenis pelanggan pada wilayah pelayanan PDAM dapat diidentifikasi dan disamakan karakteristiknya. PDAM melakukan identifikasi dan membuat daftar jenis-jenis pelanggan yang ada di wilayahnya masingmasing. Pada prinsipnya PDAM diberi kewenangan untuk menentukan keijakan dan/atau mengklasifikasikan jenis-jenis pelanggan dan memasukkan jenis pelanggan dimaksud ke dalam masing-masing kelompok yang disesuaikan dengan kondisi obyektif dan karakteristik pelanggan di daerah masing-masing sepanjang tidak mengubah jumlah kelompok pelanggan.

\section{Dasar Penetapan Tarif}

Salah satu dasar dalam penetapan tarif, terdapat prinsip pemulihan biaya. Kebijakan penetapan tarif oleh management idealnya memastikan pemulihan (recovery) atas semua biaya dan mencapai laba, dalam kondisi sulit sekalipun (Carter Usry, 2004:14). Berdasar Peraturan Menteri Dalam Negeri Nomor 23 Tahun 2006 pasal 5 disebutkan pendapatan PDAM harus memenuhi prinsip pemulihan biaya. Pemulihan biaya secara penuh (full cost recovery) dicapai dari hasil perhitungan tarif rata-rata minimal sama dengan biaya dasar. Prinsip pemulihan biaya (cost recovery), mengandung pengertian bahwa PDAM diharapkan mampu menghasilkan pendapatan yang nilainya minimal dapat menutup seluruh biaya usaha.

Menurut Sjahril Effendy (Harian Analisa, 7 Mei.2011) ada 3 kerugian bila tarif air minum tidak disesuaikan, yaitu :

a. Kerugian bagi PDAM

PDAM akan mengalami kesulitan dalam mengalokasikan investasi pengembangan pelayanan serta biaya pemeliharaan dan kualitas pelayanan cenderung menurun.

b. Kerugian Masyarakat

Tidak disesuaikannya tarif air minum berakibat rendahnya peluang masyarakat mendapatkan akses air minum / air bersih terutama masyarakat miskin dan pinggiran dan untuk memenuhi kebutuhannya terpaksa membeli air bersih dengan tarif yang relatif mahal dari pedagang air bersih / keliling perjerigen atau perkaleng.

c. Kerugian Pemda

Tidak adanya penyesuaian tarif dalam kurun waktu yang lama (lima tahun lebih), maka kerugian yang dialami Pemerintah Daerah (Pemda) adalah target cakupan pelayanan air minum melalui perpipaan cenderung statis. Retribusi Pendapatan Asli Darah yang diterima tidak meningkat dan tidak tercapainya target "Millenium

Untuk mengatasi masalah itu, Kepala BPPSPSPAM Rachmat Karnadi (Bisnis, 20 Febr.2012) menyatakan bahwa pemerintah akan merestrukturisasi PDAM yang belum menerapkan tarif di atas tarif produksi atau Full Cost Recovery, dan PDAM yang direstrukturisasi akan dilakukan evaluasi terkait kinerja finansial dan managemennya. 


\section{Penghitungan Tarif Air}

Dalam melakukan penghitungan tarif air, PDAM mengacu pada Peraturan Menteri Dalam Negeri Nomor 23 Tahun 2006 pasal 5 ayat 1 yaitu pendapatan PDAM harus memenuhi prinsip pemulihan biaya. Kemudian dalam pasal 5 ayat 2 disebutkan bahwa pemulihan biaya secara penuh (full cost recovery) dapat dicapai dari hasil perhitungan tarif rata-rata minimal sama dengan biaya dasar.

Selain untuk pemulihan biaya, tarif air minum juga harus mempertimbangkan adanya tingkat keuntungan yang wajar sebagai suatu hasil dari investigasi badan usaha. Tingkat keuntungan ini selanjutnya digunakan untuk meningkatkan kuantitas, kualitas dan kontinuitas pelayanan. Dalam Peraturan Mentri Dalam Negeri Nomor 25 thun 2006 pasal 5 ayat 4 dijelaskan bahwa tingkat keuntungan dikatakan wajar jika rasio laba terhadapaktiva produktif mencapai $10 \%$. Aktiva produktif yang dimaksud meliputi aktiva lancar, investasi jangka panjang, dan aktiva tetap, sebagaimana yang dimaksud di dalam Keputusan Menteri Dalam Negeri Nomor 47 Taun 1999 tentang Pedoman Penilaian Kinerja PDAM.

\section{Efisiensi Pemakaian Tarif}

Menurut Peraturan Menteri Dalam Negeri Nomor 23 Tahun 2006 pasal 6, efisiensi pemakaian air dicapai antara lain melalui penerapan tarif progresif. Tarif progresif adalah tarif air minum per unit (meter kubik) yang dikenakan lebih tinggi ketika penggunaan air minum oleh pelanggan melebihi standar kebutuhan pokok. Sebagai upaya mendorong efisiensi penggunaan air. Kepada pelanggan dikenakan tarif progresif untuk tingkat pemakaian air minum yang melebihi standarstandar kebutuhn pokok. Tujuan pemberlakuan tarif progresif tersebut adalah sebagai pengendalian tingkat konsumsi, konservasi air baku, dan sebagai pendapatan untuk pengembangan pelayanan.

\section{METODE PENELITIAN}

Dalam meneliti tarif air peneliti menggunakan metode penelitian kuantitatif dan data-data yang dibutuhkan berasal dari PDAM Tirta Dharma. Triwikromo (2003) mengatakan penelitian kuantitatif adalah istilah yang digunakan untuk menggambarkan pendekatan-pendekatan yang dikembangkan dalam ilmu pengetahuan alam dan kini digunakan secara luas dalam penelitian ilmu sosial. Metodemetode kuantitatif merupakan metodemetode yang didasarkan pada informasi numerik dan biasanya diasosiasiasikan dengan analisis-analisis statistik.

Dalam penelitian tarif air yang menjadi variabel penelitian adalah biaya usaha, pelanggan, produksi air bersih, dan kebocoran air. Rincian lingkup variabelvariabel tersebut adalah sebagai berikut:

a. Biaya Usaha

Biaya yang dikeluarkan untuk melaksanakan kegiatan operasional pokok perusahaan. Dalam memproduksi air bersih ada beberapa biaya usaha yang dikeluarkan yaitu biaya tetap dan biaya variabel.

b. Volume Air Terproduksi

Jumlah air yang dapat diproduksi atau dialirkan oleh PDAM

c. Tingkat Kebocoran Air

Tingkat kehilanggan air, dimana toleransi kebocoran air nasional menurut hasil audit PDAM Sleman adalah $20 \%$

\section{HASIL DAN PEMBAHASAN}

Dalam perhitungan tarif air secara full cost recovery, digunakan rumus perhitungan tarif air minum berdasarkan Peraturan Menteri Dalam Negeri Nomor 23 tahun 2006 untuk menghitung tarif dasar dasar, tarif rendah, dan tarif penuh air minum. Rumus perhitungannya adalah sebagai berikut: 
Tabel 2

Formula Perhitungan Tarif Air

\begin{tabular}{|c|c|c|c|c|c|}
\hline 3 & Tarif Rendah & & & & \\
\hline a. & TarifDasar & $\mathrm{Rp} / \mathrm{m}_{3}$ & $\mathrm{Y}$ & ID & $T D=B D$ \\
\hline \multirow[t]{2}{*}{ b. } & Volume Air Terjual kepada Kelomook & $\mathrm{m} 3 / \mathrm{Thn}$ & $\mathrm{x}$ & VTTR & Data \\
\hline & Pelanggan Tarif Rendah & & & & \\
\hline c. & Subsidi & $\mathrm{Rp} / \mathrm{m} 3$ & $Y$ & So & $\mathrm{Sb}=20 \% \times \mathrm{xD}$ \\
\hline c. & Tota1 Subsidi & $\mathrm{Rp} / \mathrm{m}_{3}$ & $\mathrm{Y}$ & TSb & $T S b=S b \times V T T R$ \\
\hline e. & Rata-rata Subsidi & $\mathrm{Rp} / \mathrm{m}_{3}$ & $\mathrm{Y}$ & RSb & $R S b=T S b / V T T R$ \\
\hline f. & Tarif Rendah & $\operatorname{Rp} / \mathrm{m}_{3}$ & $\mathrm{Y}$ & TR & $\mathrm{TR}=\mathrm{TD}-\mathrm{RS} b$ \\
\hline
\end{tabular}

\begin{tabular}{|c|c|c|c|c|c|}
\hline 4 & Tarif Penuh & & & & \\
\hline a. & Tarif Dasar & $\mathrm{Rp} / \mathrm{m} 3$ & $Y$ & ID & \\
\hline b. & Alstiva Lancar & Rp Thn & $\mathrm{x}$ & $A L$ & Data \\
\hline c. & Investasi Jangka Panjang & Rop Thn & $\mathrm{x}$ & ISP & Data \\
\hline d. & Aktiva Tetap & Rp. Thn & $\mathrm{x}$ & AT & Data \\
\hline e. & Aktiva Produktif & Rp: Thn & $\mathrm{x}$ & $A P$ & $A P=A L-I J P+A T$ \\
\hline f. & Tingkat Keuntungan & $\operatorname{Rp} / \mathrm{Thn}$ & $Y$ & TK & $\mathrm{TK}=1096 \times \mathrm{AP}$ \\
\hline g. & Volume Air Terjual Kepada Kelompol & & & & \\
\hline & Pelanggan Tarif Penuh \& Khusus & $\mathrm{m} 3 /$ Thn & $\mathrm{x}$ & VTTPK & Data \\
\hline h. & Rata-rata Tinghat Keuntungan & Rp:Thn & $Y$ & RTK & $\mathrm{RTK}=\mathrm{TK}$ VTTPK \\
\hline i. & Tota1 Subsidi & Rp:Thn & $Y$ & TSb & Sama dengan subsidi di tarifrendah \\
\hline j. & Rata-rata Subsidi Silang & Rp:Thn & $Y$ & RSbS & RsbS=TSb VITPK \\
\hline k. & Tarif Penuh & Rp. Thn & $Y$ & $\mathrm{TP}$ & $T P=T D-R T K-R s b S$ \\
\hline
\end{tabular}

Sebelum menghitung tarif air, data yang dibutuhkan adalah biaya usaha, volume air terproduksi dan terjual. Berikut data dari tahun 2009 s.d 2012:

\section{Tabel 3}

Data Biaya Usaha PDAM Sleman Tahun 2009

\begin{tabular}{|c|l|r|}
\hline Nomer & \multicolumn{1}{|c|}{ Biava } & \multicolumn{1}{|c|}{ Jumlah } \\
\hline 1 & Biaya Sumber Air & 2.827 .922 .074 \\
\hline 2 & Biaya Pengolahan Air & 382.631 .870 \\
\hline 3 & Biaya Transmisi dan Distribusi & 2.841 .049 .869 \\
\hline 4 & Biaya Umum dan Administrasi & 5.505 .616 .326 \\
\hline 5 & Biaya Keuangan & 1.761 .008 .934 \\
\hline \multicolumn{2}{|c|}{ Total Tabel 4 } & 13.318 .229 .073 \\
\hline
\end{tabular}


Data Biaya Usaha PDAM Sleman Tahun 2010

\begin{tabular}{|c|l|r|}
\hline Nomer & \multicolumn{1}{|c|}{ Biaya } & \multicolumn{1}{c|}{ Jumlah } \\
\hline 1 & Biaya Sumber Air & 2.982 .748 .859 \\
\hline 2 & Biaya Pengolahan Air & 497.279 .110 \\
\hline 3 & Biaya Transmisi dan Distribusi & 2.830 .070 .393 \\
\hline 4 & Biaya Umum dan Administrasi & 6.273 .374 .415 \\
\hline 5 & Biaya Keuangan & 362.502 .267 \\
\hline \multicolumn{2}{|c|}{ Total } & $\mathbf{1 2 . 9 4 5 . 9 7 5 . 0 4 4}$ \\
\hline
\end{tabular}

Tabel 5

Data Biaya Usaha PDAM Sleman Tahun 2011

\begin{tabular}{|c|l|r|}
\hline Nomer & \multicolumn{1}{|c|}{ Biaya } & \multicolumn{1}{|c|}{ Jumlah } \\
\hline 1 & Biaya Sumber Air & 3.650 .225 .352 \\
\hline 2 & Biaya Pengolahan Air & 558.276 .750 \\
\hline 3 & Biaya Transmisi dan Dis tribusi & 3.039 .293 .463 \\
\hline 4 & Biava Umumdan Administrasi & 6.007 .477 .738 \\
\hline 5 & Biaya Keuangan & - \\
\hline \multicolumn{2}{|c|}{ Total } & $\mathbf{1 3 . 2 5 5 . 2 7 3 . 3 0 3}$ \\
\hline
\end{tabular}

Tabel 6

Data Biaya Usaha PDAM Sleman Tahun 2012

\begin{tabular}{|c|l|r|}
\hline Nomer & \multicolumn{1}{|c|}{ Biaya } & \multicolumn{1}{c|}{ Jumlah } \\
\hline 1 & Biaya Sumber Air & 3.312 .319 .772 \\
\hline 2 & Biaya Pengolahan Air & 670.786 .501 \\
\hline 3 & Biaya Transmisi dan Distribusi & 3.068 .671 .668 \\
\hline 4 & Biaya Umum dan Administrasi & 5.549 .880 .294 \\
\hline 5 & Biaya Keuangan & - \\
\hline \multicolumn{2}{|c|}{ Total } & $\mathbf{1 2 . 6 0 1 . 6 5 8 . 2 3 5}$ \\
\hline
\end{tabular}

Tabel 7

Data Volume Air Terproduksi dan Terjual PDAM Sleman Tahun 2009

\begin{tabular}{|c|l|r|}
\hline Nomer & \multicolumn{1}{|c|}{ Keterangan } & \multicolumn{1}{c|}{ Jumlah } \\
\hline 1 & Volume Air Terproduksi & 6.421 .642 \\
\hline 2 & Volume Air Terjual untuk & 85.381 \\
\hline & Pelanggan Tarif Rendah & 205.321 \\
\hline 3 & Volume Air Terjual untuk & \\
\hline & Pelang an Tarif Penuh & \\
\hline
\end{tabular}

\section{Tabel 8}

Data Volume Air Terproduksi dan Terjual PDAM Sleman Tahun 2010

\begin{tabular}{|c|l|r|}
\hline Nomer & \multicolumn{1}{|c|}{ Keterangan } & \multicolumn{1}{|c|}{ Jumlah } \\
\hline 1 & Volume A ir Terproduksi & 6.411 .732 \\
\hline 2 & Volume A ir Terjual untuk & 82.027 \\
\hline & Pelanggan Tarif Rendah & 182.747 \\
\hline 3 & Volume A ir Terjual untuk & \\
\hline & Pelanggan Tarif Penuh & \\
\hline
\end{tabular}


Tabel 9

Data Volume Air Terproduksi dan Terjual PDAM Sleman Tahun 2011

\begin{tabular}{|c|l|r|}
\hline Nomer & \multicolumn{1}{|c|}{ Keterangan } & \multicolumn{1}{|c|}{ Jumlah } \\
\hline 1 & Volume Air Terproduksi & 5.851 .949 \\
\hline 2 & Volume Air Terjual untuk & 75.979 \\
\hline & Pelanggan Tarif Rendah & \\
\hline 3 & Volume Air Terjual untuk & 86.922 \\
\hline & Pelanggan Tarif Penuh & \\
\hline \hline
\end{tabular}

Tabel 10

Data Volume Air Terproduksi dan Terjual PDAM Sleman Tahun 2012

\begin{tabular}{|c|l|r|}
\hline Nomer & \multicolumn{1}{|c|}{ Keterangan } & \multicolumn{1}{|c|}{ Jumlah } \\
\hline 1 & Volume Air Terproduksi & 5.500 .000 \\
\hline 2 & Volume Air Terjual untuk & 81.256 \\
\hline & Pelanggan Tarif Rendah & 67.008 \\
\hline 3 & Volume Air Terjual untuk & \\
\hline & Pelanggan Tarif Penuh & \\
\hline
\end{tabular}

Tabel 11

Data Aktiva Produktif PDAM Sleman Tahun 2009 s.d 2012

\begin{tabular}{|c|c|c|}
\hline No & Tahun & Aktiva Produktif \\
\hline 1 & 2009 & 20.877 .711 .354 \\
\hline 2 & 2010 & 21.926 .031 .696 \\
\hline 3 & 2011 & 23.905 .569 .307 \\
\hline 4 & 2012 & 21.893 .410 .376 \\
\hline
\end{tabular}

Setelah menghitung tarif air dari data tahun 2009 s.d 2012, diperoleh hasil sebagai berikut:

Tabel 12

Hasil Perhitungan Tarif Air

\begin{tabular}{|r|r|r|r|}
\hline Tahun & Tarif Dasar & Tarif Rendah & Tarif Penuh \\
\hline 2009 & 2.748 & 2.198 & 13.145 \\
\hline 2010 & 2.675 & 2.140 & 14.914 \\
\hline 2011 & 3.001 & 2.401 & 31.028 \\
\hline 2012 & 3.036 & 2.429 & 36.445 \\
\hline
\end{tabular}

Hasil penghitungan tarif air kemudian dibandingkan dengan tarif air di PDAM Sleman, dengan hasil sebagai berikut:

Tabel 12

Hasil Perbandingan

\begin{tabular}{|c|c|c|c|c|c|c|c|c|c|c|c|c|}
\hline \multirow{2}{*}{ Tahren } & \multicolumn{2}{|c|}{ Tauf Dazr } & \multirow{2}{*}{ Selisì } & \multirow{2}{*}{ Kelayaian } & \multicolumn{2}{|c|}{ TarifRendah } & \multirow{2}{*}{ Seísĭ } & \multirow{2}{*}{ Kelayalian } & \multicolumn{2}{|c|}{ Taif Penth } & \multirow{2}{*}{ Selisìn } & \multirow{2}{*}{ Kelayaizon } \\
\hline & Perhitugen & PD.LN & & & Peditugan & FDAN & & & Perhitugan & PDAM & & \\
\hline 2009 & 2748 & 2200 & (345) & Tidai Layá & 2.198 & 2000 & (198) & Tadal Layati & 13145 & 4000 & (9.145) & Tidal Layal \\
\hline 2010 & 2675 & 2200 & $(475)$ & Tidal Laya & 2.401 & 2000 & (401) & Tidal Layá & 14914 & 4000 & (12914) & Tidal Laya \\
\hline 2011 & 3001 & 2200 & (801) & Tidal Layal & 2401 & 2000 & $(401)$ & Tudal Layach & 31028 & 4000 & $(27.028)$ & Tidal Layal \\
\hline 2012 & 3.096 & 2500 & (396) & Tidal Layat & 2.429 & 2250 & $(179)$ & Tidal Layai & 36445 & 5000 & (31.445) & Todak Laya \\
\hline
\end{tabular}




\section{Penghitungan Tarif Air}

Berdasarkan data dari tabel 12, perbandingan tarif air hasil perhitungan dengan tarif PDAM Sleman dapat disimpulkan bahwa tarif air PDAM Sleman belum memenuhi prinsip full cost recovery karena tarif air PDAM Sleman lebih rendah dari tarif hasil perhitungan.

Dalam perhitungan tarif dasar biaya dasar, volume produksi air dan tingkat kehilangan air terproduksi memegang peranan penting karena apabila kenaikan biaya usaha tidak dimbangi dengan kenaikan jumlah volume produksi air dan penurunan tingkat kehilangan air maka tarif dasar air akan menjadi tinggi.

Dalam perhitungan tarif rendah air, tarif dasar akan dikurangkan dengan jumlah subsidi. Jumlah subsidi yang diberikan berdasarkan formula perhitungan menurut Peraturan Pemerintah Nomor 23 Tahun 2006 sebesar $10 \%$ dari tarif dasar.

Sedangkan dalam perhitungan tarif penuh, formula yang digunakan adalah penjumlahan dari tarif dasar, rata-rata tingkat keuntungan, dan rata-rata subsidi silang. Karena itu variabel yang mempengaruhi cukup banyak yaitu jumlah aktiva produktif, volume air yang terjual kepada pelanggan tarif penuh, dan total subsidi. Data jumlah aktiva produktif dibutuhkan untuk menghitung tingkat keuntungan yaitu $10 \%$ dari jumlah aktiva produktif. Semakin tinggi jumlah aktiva produktif maka tarif penuh akan semakin tinggi. Begitu juga dengan rata-rata tingkat keuntungan, semakin tinggi aktiva produktif maka akan menambah tingkat keuntungan bila tidak diimbangi dengan pertambahan volume air yang terjual kepada pelanggan tarif penuh. Volume air terjual kepada pelanggan terif penuh juga mempengaruhi rata-rata subsidi silang, semakin banyak volume air yang terjual sibsidi akan berkurang sehingga tarif air penuh akan semakin murah.

\section{Analisis Kelayakan Tarif Air}

Dari tabel 12 juga dapat dianalisis bahwa tarif yang diberlakukan di PDAM Sleman masih belum memenuhi prinsip full cost recovery. Seluruh tarif yang diberlakukan PDAM Sleman menghasilkan nilai minus terutama untuk tarif penuh. Bila PDAM tidak memiliki pemasukan dan penjualan air minum yang aman dan bersih yang dikonsumsi masyarakat, sementara APBD pemerintah daerah terbatas, maka PDAM tidak akan memiliki modal untuk meningkatkan pelayanan dan pemeliharaan peralatan sehingga air yang didistribusikan tidak maksimal dan jelas pada akhirnya akan merugikan pelanggan.Tarif air yang layak secara ekonomi adalah tarif air yang memenuhi prinsip full cost recovery. Prinsip full cost recovery atau pemulihan biaya mengandung pengertian bahwa PDAM Sleman diharapkan mampu menghasilkan pendapatan yang nilainya minimal dapat menutup seluruh biaya usaha. PDAM Sleman diharapkan mampu mempertahankan dan meningkatkan kuantitas, kualitas, dan kontinuitas pelayanan sehingga kemudian PDAM Sleman mampu menghasilkan keuntungan yang memadai untuk pengembangan usaha dan mampu memberikan kontribusi terhadap pendapatan daerah.

\section{KESIMPULAN DAN SARAN \\ Kesimpulan}

Berdasarkan perhitungan tarif air dan analisis kelayakan tarif air di PDAM Sleman, maka didapatkan kesimpulan sebagai berikut:

a. Dari perhitungan tarif air di PDAM Sleman tahun 2009 s.d 2012 menggunakan formula penghitungan tarif air berdasar pada Peraturan Pemerintah Nomor 23 Tahun 2006, dapat disimpulkan bahwa tarif air dasar, tarif air rendah, dan tarif air penuh belum memenuhi prinsip full cost recovery

b. Tarif air yang diberlakukan di PDAM Sleman belum layak secara ekonomi karena belum dapat menutup seluruh biaya usaha atau belum memenuhi prinsip full cost recovery.

\section{Saran}

a. PDAM Sleman sebaiknya menyesuaikan tarif air sesuai dengan prinsip full cost 
recovery, agar dapat menutup biaya oprasional yang semakin tinggi.

b. PDAM Sleman sebagai BUMD, mempunyai peran penting untuk menghasilkan pendapatan dan laba. Untuk itu, secara teknis memperoleh pendapatan harus mempertinbangkan biaya dan laba yang diharapkan sehingga setiap periode akuntansi dapat menghasilkan laba yang dapat berkontribusi pada pemerintah daerah.

c. Total pendapatan setiap periode akuntansi seharusnya menghasilkan laba tanpa harus ada subsidi pemerintah daerah, tapi sebaliknya memberi kontribusi kepada pemerintah daerah. Agar dapat berkembang, diperlukan investasi modal maupun investasi sarana dan prasarana, sebaiknya asal dana untuk hal tersebut berasal dari laba setiap tahunnya yang dialokasikan sebaga investasi modal.

\section{DAFTAR PUSTAKA}

Andawayanti, Ussy, Mohammad Bisri dan Cahyani Ainin. Studi Tarif Air di PDAM Kota Malang. jurnalpengairan.ub.ac.id

Annonyymous, 2011. Badan Usaha Milik Daerah.

http://www.slemankab.go.id/358/badan -u saha-milik-daerah-bumd.slm.

Diakses pada tanggal 4 April 2011

Anonyymous, 2011. Tiga Kerugian Bila Tarif PDAM Tidak Disesuaikan. http://www.analisadaily.org/news/read/ 2011/05/18/1391/menuntut_transparan si_tirtanadi/. Diakses pada tanggal 7 Mei 2011

Anonyymous, 2012. Penyehatan PDAM: Skema Restrukturasi Disiapkan. http://archive.bisnis.com/articles/penye hatan-pdam-skema-restrukturisasidisiapkan.. Diakses pada tanggal 20 Februari 2012
Anonyymous, 2012. Realisasi Penerimaan Negara.

http://www.bps.go.id/tab_sub/view.php ?tabel $=1 \&$ daftar=1\&id_subyek=13.Dia kses pada 2012

Anonyymous, 2012. Sistem Pembayaran PDAM Jogja Belum Online Pelanggan Mengeluh.

http://www.harianjogja.com/baca/2012 /11/16/sistem-pembayaran-pdam-jogjabelum-online-pelanggan-mengeluh-

348333. Diakses pada tanggal 16 November 2012

Gunawan, Rudi. 1994. Pengantar Ilmu Bangunan. Jakarta: Kanisius

Harahap, Hamidah. 2007. Studi Pengendalian Kualitas Air PDAM Tirtanadi pada Reservoar Tuasan dan Sambungan Pelanggan. Jurnal Teknologi Proses 45-48

Harinaldi. 2005. Prinsip Statistic untuk Teknik Sains. Jakarta: Erlangga

Lubis, Irwansyah dan Rayendra L. 2010. Mengali Potnsi Pajak Perusahaan dan Bisnis dngan Pelaksanaan Hukum. Jakarta: Elex Media Komputindo

Maryono. 2006. Menilai Aksesbilitas Air Minum. Jurnal Presipitasi Volume 3 Nomor 2

Matrik, Tim. 2009. Matematika SMP/MTs Kelas 9. Jakarta: Grasindo

Peraturan Bupati Sleman Nomor 28 Tahun 2012 tentang Tarif Pelayanan Perusahaan Daerah Air Minum Sleman Peraturan Menteri Dalam Negeri Nomor 23 Tahun 2006 tentang Pedoman Teknis dan Tata Cara Pengaturan Tarif Air Minum pada Perusahaan Daerah Air Minum

Peraturan Mentri Kesehatan Republik Indonesia Nomor 
492/MENKES/PER/IV/2010 tentang

Persyaratan Kualitas Air Minum

Peraturan Presiden Republik Indonesia Nomor 29 Tahun 2009 tentang Pemberian Jaminan dan Subsidi Bunga oleh Pemerintah Pusat dalam rangka Percepatan Penyediaan Air Minum

Setiawan, Hendra dan Ade Wisni Wihandranti. 2006. Evaluasi Perhitungan Tarif Pokok Air Minum Dalam Menentukan Tarif Air Minum. Jurnal Ilmiah Ranggagading Volum 6 Nomor 1 19-23

Subagyo, Ahmad. 2007. Studi Kelayakan. Jakarta: Elex Media Komputindo
Sugianto, 2007. Pajak dan Retribusi Daerah. Jakarta: Grasindo

Sumarno, Hadi. 2005. Pilih Tarif Pasar atau Perda. Jurnal Aplikasi Managemen Volume 2 Nomor 3

Umar, Husain. 2000. Business an Introduction. Jakarta: Gramedia Pustaka Utama

Yuliarmi, Ni Nyoman dan Putu Riyasa. 2007. Analisis Faktor-Faktor yang Mempengaruhi kepusan Pelanggan Terhadap Pelayanan PDAM Kota Denpasar. Buletin Binis Volume 12 Nomor 1 tahun 2007 